\title{
Head shops and new psychoactive substances: a public health perspective
}

\author{
B. P Smyth ${ }^{1,2}$ (1) \\ ${ }^{1}$ Clinical Senior Lecturer, Department of Public Health $\mathcal{E}$ Primary Care, Trinity College Dublin, Dublin, Ireland \\ ${ }^{2}$ Consultant Child \& Adolescent Psychiatrist, Youth Drug \& Alcohol Service, HSE Addiction Service, Airton Pk, Tallaght, Dublin, Ireland
}

In 2010, Ireland found itself at the eye of an international storm as a network of head shops emerged selling new psychoactive substances (NPS) and Irish youth rapidly became the heaviest users of NPS in Europe. Within months, the Irish government enacted novel legislation, which has since been copied by other countries, which effectively stopped the head shops selling NPS. Critics of this policy argued that it could cause harms to escalate. A number of separate studies indicate that a range of drug-related harms increased amongst Irish youth during the period of head shop expansion. Within months of their closure, health harms began to decline. NPS-related addiction treatment episodes reduced and admissions to both psychiatric and general hospitals related to any drug problem began to fall. Population use underwent sustained decline. Consequently, the closure of head shops can be viewed as a success in terms of public health.

Received 07 September 2020; Revised 27 November 2020; Accepted 09 December 2020; First published online 22 January 2021

Key words: Hospital admissions, legislation, new psychoactive substances, public health, substance use disorders.

Drug policy is contentious and divisive. It can be considered and debated through many very varied lenses. Arguments about drug policy are informed by sociology, politics, behavioural psychology, economics, criminology, philosophy and public health. Given the fact that drug policy globally has been relatively uniform and stable for many decades, with an intolerant and prohibition-focussed approach being employed for most addictive psychoactive substances, there has been little real evidence about alternate models to inform debates.

As North America moves towards a more liberal approach to cannabis, this has begun to generate some real data on the advantages and disadvantages of alternative approaches (Fischer et al. 2020; Hall \& Lynskey, 2020; Murray \& Hall, 2020). It constitutes a real world experiment. Many decades ago, Campbell argued that policy should be evaluated by making use of such natural experiments, collating information 'from multiple sources of independent imperfection', as such in vivo experiments can never be controlled to the extent which would be ideal in classic scientific experiments (Campbell, 1969; Rehm \& Manthey, 2020).

Using the limited evidence base and drawing upon theories of sociology and behavioural psychology, efforts have been made to appraise the merits of different drug policy approaches. For example, Rogeberg et al. (2018) looked at the range of approaches

Address for correspondence: B. P Smyth, Youth Drug \& Alcohol Service, HSE Addiction Service, Airton Pk, Tallaght, Dublin D24, Ireland. (Email: smythbo@tcd.ie) and concluded that a regulated and legal market was the best overall policy response and would be associated with vastly less harm in all domains, including health, than a prohibition model. Indeed they concluded that an unregulated free-market would generate less harm than the current prohibition model.

\section{Arrival of head shops and new psychoactive substances to Ireland}

Ireland was presented with its own natural experiment in drug policy in 2010, finding itself at the eye of a storm. New psychoactive substances (NPS), such as mephedrone and synthetic cannabinoids were being sold in new shops, called head shops (Kelleher et al. 2011). These commercial premises proliferated rapidly across Ireland from late 2009. Many NPS have been known for a very long time, but their use escalated quickly, in Ireland and globally around this time. The expansion of head shops appears has been particularly dramatic in Ireland, reaching over 100 shops by May 2010. These businesses were supported by a large customer base, young Irish adults being the most enthusiastic NPS users in Europe and NPS use being second only to cannabis as preferred drugs in Ireland (European Commission, 2011).

Concern about NPS, especially cathinone type drugs such as mephedrone, escalated from late 2009, when there were reports of a small number of overdose deaths attributed to their use in UK and Ireland (Winstock et al. 2011). There were increasing reports of a range of other adverse health impacts, including drug induced 
psychosis, seizures and cardiac problems (Winstock et al. 2010; Papaseit et al. 2014). There were also increasing reports of very erratic and dangerous behaviour by intoxicated individuals resulting in violence. There were increasing voices urging action to address this new threat to public health, including the author.

This all occurred at a difficult time for Ireland, and indeed Europe. Recession had commenced, with rising unemployment, substantial increases in taxation and pay reductions for those who still had jobs. The people of Ireland were comparatively stoic in the face of this economic austerity. In contrast, they took to the streets to march in protest at the arrival of head shops into their towns and cities, seeing these shops and the NPS they sold as a threat to their community and their youth (McElrath \& O'Neill, 2011; Ryall \& Butler, 2011). There were instances where head shops were burnt down. This public concern was fostered by extensive media coverage of problems attributed to NPS use (See Fig. 1). In turn, this growing public unrest and media focus caused angst and debate amongst politicians and 'the head shop controversy' became a key political priority (see Fig. 1) (Ryall \& Butler, 2011). Government consequently took decisive steps which resulted in the closure of head shops over the summer of 2010 (Kelleher et al. 2011; Smyth et al. 2019).

A year later, a group of drug policy analysts looked back on this period (Ryall \& Butler, 2011). Their consensus was quite stark and critical. The public reaction was described as 'a moral panic', provoked by media coverage which was seen to be 'somewhat sensationalist'. Overall, the response by Ireland to the head shops was assessed as being 'a clear victory for the traditional "war on drugs" values'. Indeed qualitative research with people who use drugs also indicated that the closure of head shops was viewed as pointless, even possibly harmful, as all anticipated continuing to source NPS via the black market (McElrath \& O'Neill, 2011). In 2015, in the context of protracted discussions in the UK about their own policy response to NPS, the view was that use and harms continued largely unchanged in Ireland in spite of Government enacted legislation (Stevens et al. 2015). During similar debates in other countries, it was confidently predicted that there would be a rapid and smooth move of NPS supply to the criminal black market if head shops were forcibly closed, with likely increases in harms and risks (Meacher, 2013).

\section{So what policy changes did Ireland make?}

After a short period of intense debate but minimal real consultation, the Irish government initiated what emerged as a two-step process. Firstly, there was a legislative ban, adding over 100 substances to
Ireland's Misuse of Drugs Act in May 2010. This criminalised the possession, sale and supply of the added NPS, including substances such as mephedrone (Statute Book, 2010a). It marked the beginning of the end of head shops, about half of whom responded by immediately closing their doors and ceasing trade (Kelleher et al. 2011).

As opponents of this 'prohibition-styled' response had predicted, alternative NPS, such as naphyrone and flourotropococaine, which had not been listed in that legislation, did go on sale in some of those head shops which continued to operate over the summer of 2010 (El-Higaya et al. 2011; Kelleher et al. 2011; Kavanagh \& Power, 2014) In order to end this game of 'cat and mouse', the Criminal Justice (Psychoactive Substances) Act (CJPSA) was introduced in late August 2010 (Statute Book, 2010b). The CJPSA was focussed upon the vendors of NPS and sought to obstruct the arrival of further, not yet banned, NPS into the marketplace. It states that 'a person who sells a psychoactive substance knowing or being reckless as to whether that substance is being acquired or supplied for human consumption shall be guilty of an offence'.

The CJPSA was a very novel and completely untested type of legislation. No country had enacted similar legislation. There were then, and continue to be, concerns that it would be very difficult to prove 'psychoactivity' for all of these new compounds to a standard that would serve the purposes of a criminal court. Legal challenge was anticipated. During debate in the UK, prior to its implementation of very similar legislation in 2016, this Irish approach was described as 'legally flawed and scientifically problematic and potentially harmful' by Stevens et al. (Stevens et al. 2015).

In spite of its potential weaknesses as a piece of legislation in Ireland, it did succeed in persuading the head shop owners to either close shop or desist from selling NPS (Kelleher et al. 2011). About a dozen head shops remained open into 2011, but they reverted to selling drug related paraphernalia and drug memorabilia. They avoided selling any NPS, their activities being monitored closely by An Garda Síochána (Irish police force) (Kelleher et al. 2011). One head shop owner was found to be selling Salvia divinorum in April 2011 and was successfully prosecuted under the CJPSA, being later convicted and a fine imposed (Roche, 2014).

\section{What evidence is there that NPS and Head Shops were causing health harms?}

Adolescent addiction services began to notice presentations by youth involving NPS substance use disorders (SUD) in latter half of 2009 (Smyth et al. 2015). 


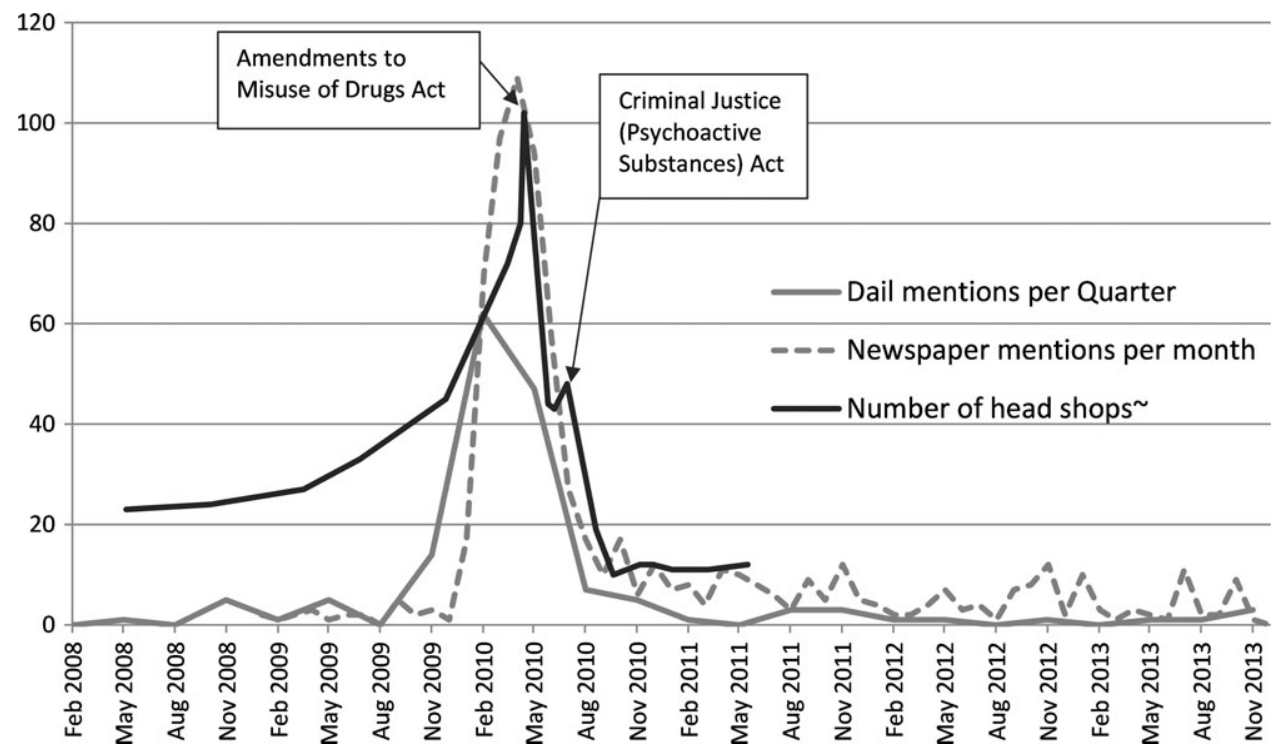

Fig. 1. Head shops and the controversy surrounding them: Numbers of head shops and number of mentions of the term "head shop" in Irish national newspapers ${ }^{\mathrm{a}}$ and in the Dail ${ }^{\mathrm{b}}, 2008-2012$.

aNumber of articles including the term 'head shop' in two national newspapers (Irish Times and Irish Independent) per month. 'The Dail is the Irish parliament. Number of mentions of the term 'head shop' in Dail debates per three-month period. Data was accessed via http:/ / oireachtasdebates.oireachtas.ie/debates\%20authoring/debateswebpack.nsf/fulltextsearch?readform. $\sim$ Number of Head shops were intermittently monitored by An Garda Síochána (Irish police service) (Kelleher et al. 2011). Exact number of head shops is unknown from Nov 2008 to Feb 2010, but has been estimated.

The Health Research Board (HRB) gathers data on addiction treatment episodes across Ireland via the National Drug Treatment Reporting System (NDTRS). Treatment providers enter the full names of the substances involved in all addiction treatment episodes into the NDTRS. NPS did not feature in treatment episodes involving adults prior in 2008. They began to emerge in late 2009 , and then escalated rapidly during the first months of 2010, as shown in Fig. 2 (Smyth et al. $2017)$. Among young adults, $4.2 \%$ of all addiction treatment episodes involved a NPS SUD while the head shops were open in 2010. Among adolescents attending addiction treatment, $82 \%$ reported recent use of NPS during the early months of 2010 , and $45 \%$ of adolescents seeking treatment in spring 2010 had a NPS SUD (Smyth et al. 2015).

In addition to addiction, there were increasing case reports of psychosis related to NPS use from Irish psychiatric hospitals (El-Higaya et al. 2011). Lally et al. (2013) conducted a survey of adults attending a mental health service in the west of Ireland while the head shops were at their peak in May 2010. They found that $24 \%$ of inpatients reported use of NPS in the past year, young males being the subgroup most likely to report use. One third of the patients reporting NPS use denied any use of illegal drugs. Most of those who did report past use of illegal drugs indicated that NPS use was now supplemented on top of that use which continued unchanged. Both findings suggest that the arrival of NPS was adding to the overall burden of drug use and not simply displacing use of traditional drugs.

The National Psychiatric In-Patient Reporting System (NPIRS) database gathers information on all psychiatric admissions into Irish hospital and notes the ICD-10 diagnoses involved. There is no method of interrogating this dataset which permits examination of specific NPS-related psychiatric admissions. However, efforts were undertaken to examine trends in the rate of psychiatric admissions related to any drug among young adults. This study revealed that drugrelated psychiatric admissions increased by $22 \%$ in 2010 relative to 2009 , with the most marked increase evident in young males, rising by over $60 \%$ in the first 5 months of 2010 as shown in Fig. 2 (Smyth et al. 2019).

The Hospital Inpatient Enquiry (HIPE) system gathers data on admissions to general hospitals. An examination of drug-related hospital admissions among young adults has also revealed that the rate of such admissions was increasing by $0.5 \%$ per month during the 30 months before the head shops were closed (See Fig. 2) (Smyth et al. 2020).

People who inject drugs (PWID) constitute a unique risk group. Some PWID commenced injection of mephedrone. This practice was associated with vasculitis and cellulitis which caused an increase in presentations of severe tissue damage to be noted at some Dublin 


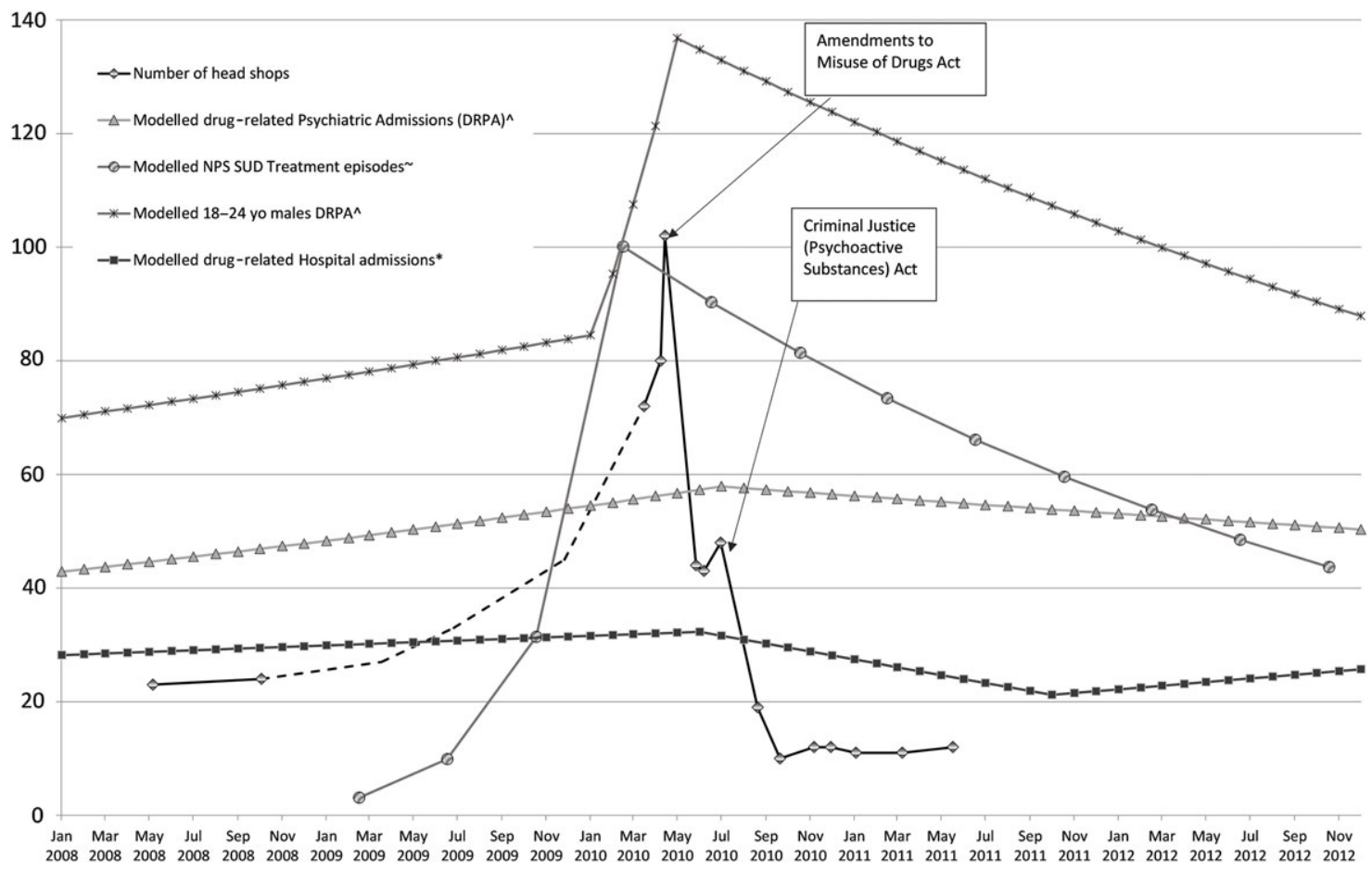

Fig. 2. Number of head shops and joinpoint models indicating changes in the rates of drug-related health harms from 2008 to 2012. $\wedge$ The joinpoint model indicates drug related psychiatric admissions (DRPA) among 18 to 34 year olds and is presenting as number of admissions per million per month, taken from Smyth et al. (2019).

$\sim$ NPS SUD, New psychoactive substance use disorders. The joinpoint model indicates NPS SUD among 18 to 34 year olds and is presenting as number of episodes per million per 4-month period, taken from Smyth et al. (2017).

*The joinpoint model indicates drug-related admissions to general hospitals among 15 to 34 year olds and is presenting as the average number of admissions per day per 10 million for each month, taken from Smyth et al. (2020).

hospitals during the early months of 2010 (Dorairaj et al. 2012).

The actual number of poisoning deaths related to NPS use was not high. While there were no poisoning deaths related to NPS in 2008, this increased to five in 2009 and six in 2010 (HRB, 2019). As awareness of NPS was only emerging at this time, it is possible that NPS may have been involved in more poisoning deaths but not tested for during post mortem toxicology.

\section{Did these markers of health harm show improvements after closure of the head shops?}

NPS-related addiction treatment episodes rapidly declined at an adolescent addiction service in Dublin after May 2010 with the initial phase of head shop closures, episodes related to use of synthetic cannabinoids falling more rapidly than those related to cathinone products (Smyth et al. 2015). One year after the commencement of head shop closures, there were no adolescent addiction episodes involving a NPS use disorder, although some teenagers continued to report low levels of NPS use. Among adults attending addiction treatment, it emerged that the rapid escalation in
NPS SUD presentations came to an abrupt end in mid-2010, and then fell consistently over the next 2 years, the rate of treatment entry dropping by $10 \%$ every 4 months (See Fig. 2) (Smyth et al. 2017).

As shown in Fig. 2, the trend analysis of psychiatric admissions among young adults found that the upward trend in admissions related to any drug use disorder came to an end in July 2010 (Smyth et al. 2019). Modelling of the trends in young males revealed that the upward trend reversed in May 2010. It then fell by $1.4 \%$ per month over the following 32 months.

While $3.0 \%$ of all hospital admissions among young adults were drug related during the head shop era of 2010, this fell by a quarter the following year and remained at this lower level over the following 5 years (Smyth et al. 2020). When examining the monthly trend (see Fig. 2), the best fitting joinpoint model indicated that the downward turn in such hospital admissions occurred in June 2010, and continued to fall by $2.6 \%$ per month over the following 16 months.

These different data sources all point to a pattern of escalating problems in the months before mid-2010 and all indicate a downward turn in those problems in mid2010, just after the head shops began to close in May 
2010. While it is clear that the change in addiction treatment episodes was NPS specific, we cannot be certain as to the cause of the escalating problems and abrupt reversal of those increases in the general drug-related hospital or psychiatric admissions (Smyth et al. 2019; Smyth et al. 2020). As shown in Fig. 2, there is strong evidence of a tight temporal connection between the closure of the head shops and the peaks in these respective harms. Clearly something seemed to cause an increase in the numbers of young adults to develop medical or psychiatric problems related to drug use. Fortunately, that trend of overall deterioration reversed in the months after the head shops began to close.

The fact that the increases and decreases in medical and psychiatric admissions coincided with rise and fall in NPS related addiction presentations adds weight to the view that closure of the head shops contributed to this positive public health impact. There is some additional support to this hypothesis from the general population survey of drug use in Ireland, which is conducted every 4 years. There was an $80 \%$ decline in the prevalence of past year NPS use by people aged 15 to 24 years between 2010 and 2014 (Smyth, 2017).

There clearly was some migration of the NPS supply to the black market and the internet (Hearne et al. 2017). While use declined, it certainly was not eliminated. There was a cluster of cases of HIV among a group of homeless older PWID in 2015 and injection of mephedrone type drugs was partly implicated in that event (Hearne et al. 2017; HPSC, 2018). The number of poisoning deaths involving NPS rose in 2013 and 2014. It has since fallen again and the vast majority of NPS poisoning deaths in recent years have involved a novel benzodiazepine called etizolam, drugs of this type not having featured at all in the Head shops during 2010 (HRB, 2019).

In addition to the above, there are further sources of evidence which suggest that the closure of head shops in Ireland had a positive public health impact. The annual report of the national self-harm registry noted an increased involvement of illicit drugs in deliberate overdoses among males, the rate rising by $50 \%$ between 2008 and 2010, and this increase being completely reversed in 2011 (Griffin et al. 2018). While involvement of NPS specifically was not included in their report, they attributed these trends to the arrival and departure of head shops.

\section{International Evaluations of legislation targeting NPS and head shops}

Internationally, there have been many studies which have found positive impacts of bans on particular NPS. These include the New Zealand banning of benzylpiperazine (BZP) in 2007 and of synthetic cannabinoids in 2010. The latter coincided with a reduction of cannabinoid-related psychiatric presentations (Glue et al. 2015; Glue et al. 2016). In Scotland, legislation targeted at NPS and headshops has also been seen to be followed by decline in NPS use among users of mental health services (Bennett et al. 2017). In the UK, separate studies indicate that medical problems related to ethylphenidate and mephedrone declined after targeted legislation (Wood et al. 2013; Yeung et al. 2017). There was a significant decline in all NPS-related medical admissions in Edinburgh following administrative efforts targeted at head shops (Pettie et al. 2018).

While the initial bans of specific NPS via the Misuse of Drugs Act in Ireland replicated similar, and equally criticised, actions undertaken around this time in a number of other countries, the CJPSA was novel and unique to Ireland. Variants of this legislation were subsequently enacted in other countries including Poland, Romania and Australia (EMCDDA, 2016). While the UK banned many specific NPS in 2010, they waited until 2016 to enact their Psychoactive Substances Act (PSA). There was substantial and vocal opposition to this Act by prominent drug policy experts (Stevens et al. 2015; Nutt, 2016). While head shops continued to operate in the UK prior to the PSA, their relative number never approached that which occurred in Ireland in 2010. Their head shops did also close down with the passage of the PSA. Evaluations of its impact have concluded a broadly positive impact with reduced NPS use by young people and declines in hospital admissions related to any drug problem, similar to Ireland (Home Office, 2018; Hill, 2020).

\section{Mechanisms via which legislation might reduce use and harms}

Is it plausible that the legal status of a drug and its sale, and changes in same, might influence use? Irish and international researchers have explored the factors which influenced the decision by drug users to use NPS specifically. In both Irish and international studies, the most common reasons given for using NPS were curiosity, legality and availability (Kelleher et al. 2011; Barratt et al. 2013; Clancy et al. 2017). Researchers in Australia and New Zealand have found that people interpret legal sale as an indication of safety and report increased willingness to use NPS in that scenario, being wary of drug dealers (Sheridan \& Butler, 2010; Champion et al. 2016). In the year that the prohibition of BZP was imposed in New Zealand, two of the three main reasons given for stopping BZP use were because it was 'illegal' and 'did not know where to get it now its illegal' (Wilkins \& Sweetsur, 2013).

The influence of legal status on decisions to use other drugs, such as cannabis has been demonstrated in 
students, who report its illegal status as a reason for avoiding use in a Canadian study (Hathaway et al. 2016). The importance of legal status of drugs was also demonstrated in the seminal follow-up studies of Vietnam veterans returning to USA (Robins, 1993). Although many had used heroin in Vietnam where they had easy access to cheap high quality heroin, few used upon their return. The reasons for avoiding use in USA included its illegal status and worries regarding criminal charges and family disapproval (Robins, 1993; Robins et al. 2010; Hall \& Weier, 2017). Most of those who had used heroin in Vietnam agreed that it should remain illegal in USA (Robins et al. 2010).

These various studies provide some clues regarding the mechanisms via which prohibition-styled legislation might influence both supply and demand for NPS. While legal and sold in shops, demand for NPS may increase as people confuse legality with safety. When made illegal, demand may fall as many people seem reluctant to migrate to drug dealers, some interpret illegality as implying greater health risk and some are put off simply by worries about criminal charges. While legal and sold commercially, supply and availability is obviously better than when made illegal, as high street shops compliment the permanently available black market. For regulated drugs such as alcohol, it is well established that increased access and availability lead to increased use and harms (Babor et al. 2010a).

\section{Is a prohibitionist policy approach to NPS consistent with a health-led drug policy?}

Ireland's national drugs strategies have had an explicit harm reduction focus over the past 20 years. Some have argued that the criminal justice system should not have any role in a policy which is 'health-led'. When considering such arguments, the international Drugs \& Public Policy Group (Babor et al. 2010b) have stated:-

The drug policy debate is dominated in many countries by false dichotomies which can mislead policy maker about the range of legitimate options and their expected impact. Law enforcement and health services approaches each contribute to the other's mission.

There are many other examples in the realm of public health where the criminal justice system is used to support health goals. Ireland, along with all other countries, utilises criminal justice measures to deliver goals of reducing deaths and injuries relating to road traffic collisions. Indeed, the bulk of the recommended actions in the latest $\mathrm{WHO}$ report on reducing morbidity and mortality focus on such legislative and enforcement measures (WHO, 2020). The prompt delivery of high quality post-crash health care is the only direct health provided intervention. An Garda Síochána have been prominent in supporting population adherence to 'lock down' restrictions during the recent health led societal response to the Covid-19 pandemic. Efforts to curtail gunshot injuries include criminalisation of almost all gun-related activities in Ireland.

The criminal justice system and health system are not opponents (Babor et al. 2010b). The health system has a crucial role in provision of treatment to people who experience problems related to their drug use, such as addiction, mental disorders and medical problems. The criminal justice system can have a role in supporting prevention by deterring both use and sale of drugs, and it operates alongside a suite of other prevention initiatives all built around goals of protecting and maintaining health. The proportionality of criminal justice responses should always be kept under review, seeking to identify the least harsh and intrusive measures to deter drug use and selling.

\section{Conclusions}

Overall, there is substantial evidence that a range of drug-related health harms were escalating during the months of head shop expansion in Ireland from late 2009 to May 2010. NPS SUD escalated very rapidly, especially in younger age ranges. Admissions to both psychiatric and general hospitals related to drug use increased substantially and significantly. The expressions of concern at that time therefore appear to have been grounded in reality and it seems unreasonable to dismiss them as being a media driven 'moral panic'.

Government action was unusually prompt and decisive. It achieved its goal of cessation of NPS sale by head shops. Within a couple of months, all of the healthrelated harms, which had been rising, began to fall. There has been some migration of NPS supply to the internet and black markets. This remains a concern and harms will need to be kept under review.

Given that the network of head shops functioned as a commercialised and unregulated drug regime, these results challenge the conclusions of Rogeberg et al. (2018), as it seemed to bring an increase in harms and the return to a prohibition orientated model coincided with health gains. Their modelling had suggested that the opposite should occur. Taking all of the available evidence together, and accepting that each of the various data sources has its own 'independent imperfections', it seems that Government action in Ireland on head shops was both warranted and effective when considered through the lens of public health.

\section{Financial support}

This research received no specific grant from any funding agency, commercial or not-for-profit sectors. The 
author is employed by the Health Service Executive, but the views expressed do not necessarily reflect those of his employer.

\section{Conflict of interest}

BPS did publicly advocate for political action to be taken to address sale of NPS by head shops in 2010 .

\section{Ethical standards}

The author asserts that all procedures contributing to this work comply with the ethical standards of the relevant national and institutional committee on human experimentation with the Helsinki Declaration of 1975 , as revised in 2008. The authors assert that ethical approval for publication of this perspective piece was not required by their local Ethics Committee.

\section{References}

Babor T, Caetano R, Casswell S, Edwards G, Giesbrecht N, Graham K, Grube J, Hill L, Holder H, Homel R, Livingston M, Österberg E, Rehm J, Room R, Rossow I (2010a). Alcohol: No Ordinary Commodity: Research and Public Policy, 2nd edn., Oxford University Press: New York, NY.

Babor T, Caulkins JP, Edwards G, Fischer B, Foxcroft D, Humphreys K, Obot I, Rehm J, Reuter P, Room R, Rossow I, Strang J (2010b). Drug Policy and the Public Good. Oxford University Press: Oxford, UK.

Barratt MJ, Cakic V, Lenton S (2013). Patterns of synthetic cannabinoid use in Australia. Drug and Alcohol Review 32, 141-146.

Bennett KH, Hare HM, Waller RM, Alderson HL, Lawrie S (2017). Characteristics of NPS use in patients admitted to acute psychiatric services in Southeast Scotland: a retrospective cross-sectional analysis following public health interventions. BMJ Open 7, e015716.

Campbell DT (1969). Reforms as experiments. American Psychologist 24, 409-429.

Champion KE, Teesson M, Newton NC (2016). Patterns and correlates of new psychoactive substance use in a sample of Australian high school students. Drug and Alcohol Review 35, 338-344.

Clancy RV, Hodgson RC, Kendurkar A, Terry MA, Dadd L, Clancy DM, Ryan K, Hatzistylis M, Tinman BG (2017). Synthetic cannabinoid use in an acute psychiatric inpatient unit. International Journal of Mental Health Nursing 27, 600-607.

Dorairaj J, Healy C, McMenamin M, Eadie PA (2012). The untold truth about "bath salt" highs: a case series demonstrating local tissue injury. Journal of Plastic, Reconstructive \& Aesthetic Surgery 65, e37-e41.

El-Higaya E, Ahmed M, Hallahan B (2011). Whack induced psychosis: a case series. Irish Journal of Psychological Medicine 28, S11-S13.
EMCDDA (2016). Perspectives on Drugs: Legal Approaches to Controlling New Psychoactive Substance. European Monitoring Centre for Drugs and Drug Addiction: Luxembourg.

European Commission (2011). Youth attitude on drugs. European Commission: Brussels.

Fischer B, Bullen C, Elder H, Fidalgo TM (2020). Considering the health and social welfare impacts of non-medical cannabis legalization. World Psychiatry 19, 187-188.

Glue P, Courts J, Gray A, Patterson T (2016). Influence of law changes affecting synthetic cannabinoid availability and frequency of hospital presentations: 4-year national survey. New Zealand Medical Journal 129, 37-40.

Glue P, Courts J, MacDonald M, Gale C, Mason E (2015). Implementation of the 2013 Psychoactive Substances Act and mental health harms from synthetic cannabinoids. New Zealand Medical Journal 128, 15-18.

Griffin E, McTernan N, Wrigley C, Nicholson S, Arensman E, Williamson E, Corcoran P (2018). National Self-Harm Registry Ireland Annual Report. National Suicide Research Foundation: Cork.

Hall W, Lynskey M (2020). Assessing the public health impacts of legalizing recreational cannabis use: the US experience. World Psychiatry 19, 179-186.

Hall W, Weier M (2017). Lee Robins' studies of heroin use among US Vietnam veterans. Addiction 112, 176-180.

Hathaway A, Mostaghim A, Kolar K, Erickson PG, Osborne G (2016). A nuanced view of normalisation: attitudes of cannabis non-users in a study of undergraduate students at three Canadian universities. Drugs: Education, Prevention and Policy 23, 238-246.

Hearne E, Wells J, Van Hout MC, The Home Programme of the European Commission (2017). Country report on New Psychoactive Substances in Ireland. Waterford Institute of Technology: Waterford.

Hill RG (2020). Understanding the UK psychoactive substances act. British Journal of Clinical Pharmacology 86, 499-504.

Home Office (2018). Review of the Psychoactive Substances Act 2016. Home Office: London.

HPSC (2018). Drug-Related Bloodborne Viruses in Ireland 2018. Health Protection Surveillance Centre: Dublin.

HRB (2019). National Drug-Related Deaths Index 2008-2017 Data. Health Research Board: Dublin.

Kavanagh PV, Power JD (2014). New psychoactive substances legislation in Ireland - Perspectives from academia. Drug Testing and Analysis 6, 884-891.

Kelleher C, Christie R, Lalor K, Fox J, Bowden M, O'Donnell C (2011). An Overview of New Psychoactive Substances and the Outlets Supplying Them. National Advisory Committee on Drugs: Dublin.

Lally J, Higaya E-E, Nisar Z, Bainbridge E, Hallahan B (2013). Prevalence study of head shop drug usage in mental health services. The Psychiatrist Online 37, 44-48.

McElrath K, O'Neill C (2011). Experiences with mephedrone pre- and post-legislative controls: Perceptions of safety and sources of supply. International Journal of Drug Policy 22, 120-127. 
Meacher MC (2013). Drug policy reform-The opportunity presented by 'legal highs'. The Psychiatrist 37, 249-252.

Murray RM, Hall W (2020). Will legalization and commercialization of cannabis use increase the incidence and prevalence of psychosis? JAMA Psychiatry 77, 777778.

Nutt D (2016). 'Psychoactive Substances Bill - Flawed Rationale and Huge Potential for Increase in Harms'. In Drug \& Alcohol Policy. University of Bath.

Papaseit E, Farre M, Schifano F, Torrens M (2014). Emerging drugs in Europe. Current Opinion in Psychiatry 27, 243-250.

Pettie J, Burt A, Knipe DW, Torrance H, Dow M, Osinski K, Greig R, Sabatini D, Easterford K, Dear J, Eddleston M (2018). New drug controls and reduced hospital presentations due to novel psychoactive substances in Edinburgh. British Journal of Clinical Pharmacology 84, 2303-2310.

Rehm J, Manthey J (2020). Cannabis and public health: a global experiment without control. World Psychiatry 19, 192-194.

Robins LN (1993). The sixth Thomas James Okey Memorial Lecture. Vietnam veterans' rapid recovery from heroin addiction: a fluke or normal expectation? Addiction 88, 1041-1054.

Robins LN, Helzer JE, Hesselbrock M, Wish E (2010). Vietnam veterans three years after Vietnam: how our study changed our view of heroin. The American Journal on Addictions 19, 203-211.

Roche B (2014). Headshop owner fined $€ 15,000$ over hallucinogenic drug: Substance became illegal with introduction of new legislation in 2010, court hears. In Irish Times. (https://www.irishtimes.com/news/ireland/ irish-news/headshop-owner-fined-15-000-overhallucinogenic-drug-1.1704208). Accessed 27 November 2020.

Rogeberg O, Bergsvik D, Phillips LD, van Amsterdam J, Eastwood N, Henderson G, Lynskey M, Measham F, Ponton R, Rolles S, Schlag AK, Taylor P, Nutt D (2018). A new approach to formulating and appraising drug policy: a multi-criterion decision analysis applied to alcohol and cannabis regulation. International Journal of Drug Policy 56, 144-152.

Ryall G, Butler S (2011). The great Irish head shop controversy. Drugs: Education, Prevention \& Policy 18, 303-311.

Sheridan J, Butler R (2010). “They're legal so they're safe, right?" What did the legal status of BZP-party pills mean to young people in New Zealand? International Journal of Drug Policy 21, 77-81.

Smyth B, Daly A, Elmusharaf K, McDonald C, Clarke M, Craig S, Cullen W (2019). Legislation targeting head shops selling new psychoactive substances and changes in drug related psychiatric admissions: a National database study. Early Interventions in Psychiatry 14, 53-60.

Smyth B, O'Farrell A, Cullen W (2020). Drug related medical hospital admissions during and after a period of head shop expansion. European Journal of Public Health, ckaa171. doi: 10.1093/eurpub/ckaa171.

Smyth BP (2017). New psychoactive substances in Ireland following the criminal justice (psychoactive substances) act—why all the pessimism? Addiction 112, 1686-1686.

Smyth BP, James P, Cullen W, Darker C (2015). "So prohibition can work?" Changes in use of novel psychoactive substances among adolescents attending a drug and alcohol treatment service following a legislative ban. International Journal of Drug Policy 26, 887-889.

Smyth BP, Lyons S, Cullen W (2017). Decline in new psychoactive substance use disorders following legislation targeting headshops: evidence from national addiction treatment data. Drug and Alcohol Review 36, 609-617.

Statute Book (2010a). Misuse of Drugs (Amendment) Regulations 2010. Irish Statute Book: Dublin.

Statute Book (2010b). Criminal Justice (Psychoactive Substances) Act 2010. Irish Statute Book: Dublin.

Stevens A, Fortson R, Measham F, Sumnall H (2015). Legally flawed, scientifically problematic, potentially harmful: the UK Psychoactive Substance Bill. International Journal of Drug Policy 26, 1167-1170.

WHO (2020). European Regional Status Report on Road Safety 2019. WHO Regional Office for Europe: Copenhagen.

Wilkins C, Sweetsur P (2013). The impact of the prohibition of benzylpiperazine (BZP) 'legal highs' on the prevalence of BZP, new legal highs and other drug use in New Zealand. Drug and Alcohol Dependence 127, 72-80.

Winstock A, Mitcheson L, Ramsey J, Davies S, Puchnarewicz M, Marsden J (2011). Mephedrone: use, subjective effects and health risks. Addiction 106, 1991-1996.

Winstock AR, Marsden J, Mitcheson L (2010). What should be done about mephedrone? BMJ 340, c1605.

Wood DM, Greene SL, Dargan PI (2013). Emergency department presentations in determining the effectiveness of drug control in the United Kingdom: mephedrone (4-methylmethcathinone) control appears to be effective using this model. Emergency Medicine Journal 30, 70-71.

Yeung A, Weir A, Austin H, Morrison K, Inverarity D, Sherval J, Henderson N, Joshi S, Ure R, McAuley A (2017). Assessing the impact of a temporary class drug order on ethylphenidate-related infections among people who inject drugs in Lothian, Scotland: an interrupted time-series analysis. Addiction 112, 1799-1807. 